\title{
A Qualitative Exploration of Culturally-Pluralistic Segmentation among Millennials
}

\author{
Lori M. Thanos ${ }^{1} \&$ Sylvia D. Clark ${ }^{2}$ \\ ${ }^{1}$ St. Joseph's College, Business and Marketing Department, Brooklyn, New York, USA \\ ${ }^{2}$ St. John's University, Tobin School of Business, Staten Island, New York, USA \\ Correspondence: Dr. Lori M. Thanos, St. Joseph's College, Business and Marketing Department, Brooklyn, New \\ York, USA. E-mail: lorithanos@yahoo.com
}

Received: June 29, 2017 Accepted: July 14, 2017 Online Published: July 28, 2017

doi:10.5539/ijms.v9n4p1 URL: http://doi.org/10.5539/ijms.v9n4p1

\begin{abstract}
The purpose of this study was to examine the possible existence of culturally-pluralistic segmentation based on perceptions of U.S. Millennials attending college in New York City. The present research posits that this key cohort, the culturally-pluralistic consumer, i.e., one who has many cultural associations but only one of those cultures presents as dominant, has the propensity for being grouped as an identifiable market segment. Utilizing a qualitative case study approach, twelve face-to-face interviews were conducted with Millennials from a New York City community college. The objective was to explore participants' perceptions as to how their cultural associations influence their food purchase and consumption behaviors, particularly with regard to ethnic foods. Findings concluded that Millennials are aware of cultural pluralism and deem themselves culturally-adept, self-identifying with cultures other than their original family bloodlines. Participants' tendencies were inclined toward choosing ethnic foods from a singular dominant culture from among their various cultural connections and associations. The results from this study support cultural pluralism as a segmentation method and can be used to add to current literature as well as for marketers to develop strategy.
\end{abstract}

Keywords: consumer behavior, market segmentation, cultural pluralism, millennials, ethnic foods, financial crisis 2008

\section{Introduction}

Millennials are capturing the attention of many major industries in today's business marketplaces because of their size, ability to transform various areas of commerce, and distinct attributes (Kruger \& Saayman, 2015; Valentine \& Powers, 2013). According to the U.S. Census Bureau (2015), Millennials are the largest population since the Baby Boomers, representing about one-quarter of the nation's inhabitants, with more than $\$ 200$ billion in annual purchasing power (Kruger \& Saayman, 2015; Valentine \& Powers, 2013). Millennials' food spending is expected to increase by $\$ 50$ billion each year through 2020 (Ascarelli, 2015; Peregrin, 2015). Millennials' purchasing power and propensity toward food spending, particularly organics, make them an extremely attractive market segment for food marketers and producers to pursue.

\section{Literature Review}

\subsection{U.S. Food Market and Ethnic Foods}

Cranfield (2013) posited that an ever-growing, globally-diverse population is increasing demand in the food market, particularly ethnic foods, leading to global dietary acculturation (Cleveland, Rojas-Mendez, Laroche, \& Papadopoulos, 2016; Cranfield, 2013; Demangeot \& Sankaran, 2012; Lindridge, Vijaygopal, \& Dibb, 2014). This phenomenon is prompting many restaurants in the New York City area to target Millennials for their preference of ethnic, organic food choices (Lutz, 2015; Peregrin, 2015; Simpson, 2015).

Macharia, Collins, \& Sun's (2013) case study showed the Millennial cohort favoring fresh foods from street vendors, supporting consumer segmentation based on food product preferences in the agrifood context (Macharia et al., 2013). Demangeot \& Sankaran (2012) proposed an experimentalism strategy: new migrants and current residents choose foods based on a combination of cultural influences.

Cleveland, Laroche, \& Papadopoulos (2015) used a survey to study food consumption. Food consumption is 
more than a means of nourishment; rather, it plays a conspicuous part in shaping attitudes toward cultural identification stemming from social norms inculcated by family, reference groups, and the food industry (Bartikowski \& Walsh, 2015; Cleveland et al., 2016). The authors found a strong connection between ethnic tradition, and eating habits and meals with global consumer culture. The study also demonstrated that experiencing ethnic foods affords people the opportunity "to take on different identities, as appropriate to the consumption context or regarding which particular consumer role is operant" (p. 545).

Existing knowledge about Millennials' preferences reveals that cultural influence on consumption patterns and habits is important, particularly for food products. This study explores cultural pluralism among Millennials in the U.S. food market, specifically ethnic foods. According to The Hartman Group (2014), Millennials make distinct choices in their product consumption, particularly in their food choices. Millennials are zealous and informed about environmental and social issues (e.g., organic, non-GMO). They want to personally connect with a brand and this desire greatly influences their food consumption choices. Thus, their cultural identification is significant to the marketer (Demangeot \& Sankaran, 2012; The Hartman Group, 2014).

\subsection{Culturally Pluralistic Millennials as a New Market Segment}

\subsubsection{Cultural Pluralism}

Craig and Douglas (as cited in Demangeot \& Sankaran, 2012) defined cultural pluralism as "the phenomenon describing individuals within a culture exhibiting elements of multiple cultures - as a result of a transition between cultures or close contact with different cultures" on the individual level (p. 762). Consumer behavior researchers need to comprehend how purchase and consumption are culturally-rooted and utilized to build and sustain a culturally-interpreted self-identity (Lindridge et al., 2014).

Further, many researchers interchange cultural pluralism with multiculturalism in certain contexts, creating ambiguity in research, understanding, and application (Butculescu, 2014; Demangeot \& Sankaran, 2012; Pakulski, 2014). Multiculturalism is a negotiation of complex cultural identities considering persons with influence from more than one culture, where no one culture is dominant over the others. However, cultural pluralism suggests that although an individual may exhibit behaviors influenced by multiple cultures, one culture tends to be more dominant than the others (Demangeot \& Sankaran, 2012; Kipnis et al., 2013; Pakulski, 2014; Pantoja, Perry, \& Blourock, 2014). Moreover, "Cultural identity entails a person's attempt to self-identify and be identified by others as a member of one or several cultural groups" (Kipnis et al., 2013, p. 1187).

Demangeot \& Sankaran's (2012) study uncovered four cultural pluralism strategies: (a) cultural experimentalism characterizes the ongoing search for practices and products from other cultures; (b) cultural extensionism describes a cautious strategy that leads consumers beyond their purchase of culturally-familiar products toward those of other cultures; (c) cultural purism describes a selective method geared toward culturally-cued products, and (d) cultural passivity denotes disinterest or lack of involvement with other cultures.

With the growth of sociocultural diversity across and within many nations, directly due to transient and immigration mobility and indirectly through intercultural contact possibilities via global media, marketers and researchers alike must take a new slant on how they interpret cultural association and their influences on marketing strategy, particularly segmentation.

Five countries were used in Calabrese, Capece, Costa, \& Di Pillo's (2015) cross-cultural study. Hofstede's Model of Cultural Dimensions was used as the basis for analyzing cultural suitability for T.V. commercial development for a well-known soft-drink company. The study included focus groups through Skype, social network fan forums, Twitter and Facebook, followed by five phenomenological interviews. A spike in cultural interest in global marketing is offered as the primary explanation for disparities in consumer behavior across various countries (Cleveland et al., 2016). The researchers asserted that accurate culture definition, based on consumers' perception of the culture to which they belong, not just birth-given culture, greatly influences their purchases.

Cleveland et al. (2015) surveyed over 2,000 Millennial college students in eight countries. Purposive sampling incorporating a wide array of measures was used. These measures encompassed multiple languages and many items to address each of the multilayered cultural consumer dispositions and concepts, including relevant demographics and food patterns. Two components (interpersonal and media) were linked to global acculturation; consumer dispositions (materialism, consumer ethnocentrism, and cosmopolitanism); ethnic identity and various food consumptions. Each country varied in terms of culture, historical legacies, economics, linguistics, and sociodemographic aspects. MANCOVA was utilized to analyze the variables. The identification of several acculturation patterns in food purchase and consumption along with other cosmopolitanism behaviors were reported. Two consistent elements for ethnic identity emerged as well: "identification with/desire to maintain 
ethnic identity and intra-ethnic interpersonal relations" (Cleveland et al., 2015, p. 547).

Carpenter, Moore, Alexander, \& Doherty's (2013) study of cross-sectional consumers in the U.S. suggests individualism and demographics, to varying degrees, influence four dimensions of the "acculturation to the global consumer culture (AGCC)" (p. 271). Issues and methods were highlighted to homogenize attitudes and cultural beliefs about food consumption, concluding that developing a homogeneous consumer culture is imperative to marketers in the global marketing environment (Demangeot \& Sankaran, 2012; Kipnis et al., 2013; Surugiu \& Surugiu, 2015). Subsequently, multiple regression analysis determined effects of AGCC cultural values and consumer demographics. The results confirmed acculturation of the global consumer culture.

Cleveland et al.'s (2016) quantitative, cross-national study surveyed 466 Millennial undergraduate/graduate students from two countries. The covariates controlled were education, income, and gender used in the MANCOVA and correlation analyses. The study focused on globalization and cultural change-identity, culture, dispositions and behavior. The researchers found disparities across countries in consumer behavior which lie squarely in cultural orientation. They also uncovered miscomprehension of current versus traditional cultural meanings. They compared Canadian and Chilean consumption patterns as affected by acculturation to global consumer culture (AGCC) and national identity (NID). The results primarily supported two hypotheses which specifically addressed behaviors toward food consumption.

\subsubsection{Millennials}

Ford, Jenkins \& Oliver (2012) noted that the Millennial generational cohort is destined to become the largest American populace since the Baby Boomers. Wielding purchase power of $\$ 200$ billion annually, venerating status consumption with self-centric and pleasure-seeking values, Millennials are deemed a highly desirable segment, making up almost a third of the American population (Debevec, Schewe, Madden, \& Diamond, 2013; Kruger \& Saayman, 2015; Ntanos, Skordoulis, \& Ntanos, 2014).

Peregrin's (2015) article posited that Millennials are quite conscious of and actively pursue healthy eating, seeking out food products that emphasize health benefits; they are very nutrition-savvy. This generation craves an experience with their food consumption, which bodes well for ethnically-themed restaurants. Peregrin (2015) surveyed 2,116 participants collected from the Food Marketing Institute's (FMI's) 2014 US Grocery Shopper Trends Report. Millennials are amenable to seeking out ethnic, natural, and organic foods; they have a willingness to pay more for fresh and healthy food and are willing to go out of their way to find these foods (McGrath, 2014).

Recognizing that Millennials value organic, natural food products, Chipotle Mexican Grill USA has made some bold changes to its menu by removing genetically-modified organisms (GMO) ingredients from its food in the hope of attracting more young Americans (Kell, 2015). Ells, the founder of Chipotle, notes that "Millennials are willing to pay a little more for something they recognize as better", (Kell, 2015, para. 1). According to a 2015 Nielsen study, 43\% of Americans considered non-GMOs extremely important in their food choices ("We are what we eat", 2015). The youngest generation is the most willing to pay higher prices for non-GMO foods, with Millennials at 29\%, compared to Generation X (26\%) and Baby Boomers (23\%). Chipotle often foregoes profit in the short run to accommodate and preserve a pristine image among its Millennial customers by using healthier, more expensive ingredients (Kell, 2015).

Chipotle stated in its 2015 annual report, "there is still a need to introduce our brand to new customers and engage with existing ones in other ways, by helping them understand what makes Chipotle different than other restaurants" (Chipotle Mexican Grill, USA., 2015). As a national leader in the fast-food industry, Chipotle is at number 54 on Fortune's list of 100 fastest-growing companies (Kaplan, 2011). Chipotle's desire to connect with new and existing customers in unique and profitable ways, coupled with its rapidly-expanding locations, makes Chipotle an ideal case study for a new form of successful marketing strategy: culturally-pluralistic segmentation (Chipotle Mexican Grill, 2015; Choi, 2014; "Number of Chipotle Mexican Grill restaurants worldwide...," 2016). Total stores in 2015 numbered better than 2,000, almost five percent in the New York City area with average sales of $\$ 2.2$ million per restaurant ("Number of Chipotle Mexican Grill restaurants worldwide...," 2016).

\section{Method}

A qualitative case study was utilized to uncover cultural pluralism segmentation based on perceptions of U.S. Millennials attending community college in New York City. The goal was to determine a connection between Millennials who are culturally pluralistic and their food consumption and purchase behaviors through a variety of questions directly related to these variables. The sample comprised 12 Millennial students, males and females, 
aged 18 and 36. The sampling frame was a Northeastern community college with approximately 25,000 business students. Purposive sampling was used for student selection. Professors read a recruitment letter crafted by the researcher to various classes, inviting students to participate.

Face-to-face depth interviews of 25 to 45 minutes each were conducted using semi-structured questions at Chipotle Mexican Grill, USA, one block from the community college. Chipotle Mexican Grill, USA, ("Chipotle") highlights its organic ingredients and multicultural food recipes to appeal to the multi-cultured Millennial (Lutz, 2013; Melgoza, 2015; Simpson, 2015). With growth of 11 percent in one year versus the annual growth of 1.1 percent for classic fast food restaurants, Chipotle is becoming synonymous with quality ethnic dining while maintaining its place in the typical fast-food market segment as an affordable and convenient eating choice among Millennials (Lutz, 2013; Patton, 2014; Simpson, 2015; Trefis Team, 2014).

Responses, including verbatims and researcher observations (e.g., body language and facial expressions), were used to support Millennials' eagerness to express culturally-pluralistic tendencies in their food consumption habits (Fielding, Fielding, \& Hughes, 2013). Questions (see Appendix A) were validated by professional market researchers prior to conducting the interviews.

Determination of participant coding relied on the accumulation of similar and dissimilar variables. The coding scheme of the variables included participant characteristics, cultural identification, and food consumption patterns. Initial codes were defined with associated phrases and terms (Creswell, 2013). Only one of the two researchers manually analyzed the data from the interview transcripts to determine whether one cultural influence presented as dominant in the Millennials' food purchases and consumption habits; therefore, no intercoder reliability testing was necessary.

Content analysis involved evaluating text, systematic coding and theme identification for participant responses, with an eye toward addressing the research questions. NVivo, the content analysis software, was used to this end (Creswell, 2013; Grbich, 2013). Cultural identity related to purchase and consumption behaviors from cultures or countries different from those of participants was the basis for the categories. "Food is the most common consumption category and is often ethnically cued" (Demangeot \& Sankaran, 2012, p. 769).

\section{Results}

For this qualitative case study, a primary research question to establish breadth, depth, and boundaries was drafted. Related themes and patterns and summarized results of the investigation are provided.

Q1. What culturally-pluralistic marketing elements exist as perceived by New York City college Millennials in the U.S. food marketplace?

\subsection{Demographic Profile of Study Participants}

This sample of participants is NYC Millennials who are recognized by the U.S. Census Bureau (2014b) as being multi-cultured. Four participants were female, eight were male, all between 18 and 36 years of age. All participants' education was community college level. The results supported the Census Bureau's 2014 projections (U.S. Census Bureau, 2014a, 2014b).

\subsubsection{Demographic Cultural Frequencies}

All participants were multicultural, with 11 of 12 having four or more cultures influencing their food purchase and consumption habits. Half had been born in NYC; the other half were born in the Caribbean, Africa, or South America. Six participants included Italian food among their food consumption influences but did not have an Italian bloodline. Table 1 shows that Millennial students eat more ethnic food types than reflected in their family bloodline. Of 64 ethnic food types, only 16 occurrences were associated with family bloodlines. Mexican is the most popular ethnic food, with nine occurrences of food purchase and consumption influence, although none of these participants was of Mexican descent. Similarly, the Asian ethnic food influence is derived from only friends and associates and /or other tendencies, not from family cultural bloodlines. 
Table 1. Demographic cultural frequencies

\begin{tabular}{|c|c|c|c|c|}
\hline \multirow[b]{2}{*}{ Ethnic Food Type } & \multicolumn{4}{|c|}{ Number of Students } \\
\hline & Food Purchase Influence & Food Consumption Influence & $\begin{array}{l}\text { Family Cultural } \\
\text { Bloodline }\end{array}$ & $\begin{array}{l}\text { Friends' \& Associates' } \\
\text { Cultural Affiliations }\end{array}$ \\
\hline Arabic & 1 & 1 & 0 & 0 \\
\hline Armenian & 1 & 1 & 0 & 0 \\
\hline Asian & 12 & 12 & 0 & 10 \\
\hline Botswanan & 1 & 1 & 0 & 0 \\
\hline Caribbean & 2 & 2 & 0 & 0 \\
\hline Dominican & 1 & 3 & 1 & 7 \\
\hline Ethiopian & 1 & 1 & 0 & 0 \\
\hline French & 2 & 2 & 2 & 2 \\
\hline German & 0 & 1 & 0 & 1 \\
\hline Greek & 2 & 2 & 0 & 0 \\
\hline Guyanese & 2 & 2 & 0 & 6 \\
\hline Haitian & 1 & 2 & 1 & 5 \\
\hline Hispanic & 2 & 2 & 0 & 0 \\
\hline Indian & 4 & 4 & 1 & 2 \\
\hline Islamic & 1 & 1 & 0 & 0 \\
\hline Italian & 5 & 6 & 0 & 3 \\
\hline Jamaican & 5 & 5 & 4 & 5 \\
\hline Latino & 1 & 0 & 0 & 0 \\
\hline Mexican & 9 & 9 & 0 & 6 \\
\hline Mozambican & 2 & 2 & 1 & 1 \\
\hline Peruvian & 1 & 1 & 0 & 1 \\
\hline Portuguese & 1 & 1 & 0 & 1 \\
\hline Puerto Rican & 0 & 2 & 1 & 3 \\
\hline Punjabi & 0 & 1 & 0 & 0 \\
\hline Senegal & 1 & 1 & 1 & 2 \\
\hline Trinidadian & 3 & 3 & 2 & 6 \\
\hline Turkish & 2 & 2 & 0 & 0 \\
\hline Venezuelan & 1 & 1 & 2 & 2 \\
\hline TOTAL & 64 & 71 & 16 & 63 \\
\hline
\end{tabular}

Note. Answers provided by study participants via the interviews.

\subsection{Themes}

\subsubsection{Answer/Theme 1. Cultural Pluralism Recognition / Existence}

Four themes emerged from the analysis. Ethnic food purchase and consumption different from the participants' bloodline background was strongly evident. An overwhelming desire to convey cultural connections, particularly with non-bloodline cultures, was present in the findings. Participants expressed eagerness to try different ethnic foods, and were open to respecting and even assimilating into cultures other than their own original cultural bloodlines.

Six participants recognized cultural pluralism as identifying with a single culture from among many in their lives. Five participants had a partial understanding of the cultural pluralism concept or similar ideas from their marketing and sociology classes. All but one of the participants believed cultural pluralism had something to do with multiple cultures having an influence on consumption or activities in a person's life. According to Student $\# 4$, “... culture is how you define yourself, how you identify yourself, who you are and which group of people you represent, regardless of where you come from or where you live."

Seven participants stated outright that among all the cultures with which they come in contact, one presents as dominant when purchasing and consuming ethnic foods. "Mexican culture is most dominant to me," said Student \#11. Student \#5 said, "If I have the choice, I pick Italian food over any other kind of food." Student \#9 asserted, "I enjoy ads which try to reach me on my distinct cultural identification-a black woman with a Mexican affiliation. So, I always go for Mexican food instead of anything else." Further, Student \#8 noted with a grin, "I feel like Italian food would be a dominant choice for me because a lot of my friends are from Italy — I identify with this culture." 


\subsubsection{Answer/Theme 2. Cultural Self-identification}

Forty-three instances of cultural "identify," "identifies," "identities," and "identification" were returned from an NVivo word frequency query. Six participants identified with only one single culture among the many cultures with which they were associated regardless of family bloodlines. Four participants claimed to self-identify with non-family bloodline cultures. For example, Student \#4 verbalized cultural identification as follows: "I had to assimilate; however, I remain true to my original culture. I believe culture is how you define yourself, how you identify yourself." Student $\# 5$, while admitting cultural influence from mom because mom did most of the cooking, told the researcher, "When I'm with friends, I just eat what they eat. I identify with the Italian culture."

\subsubsection{Answer/Theme 3. Openness to / Influence of Different Cultures from an individual'S Cultural Bloodlines}

All participants self-identified as multicultural. Among the most common cultures of influence were Mexican, Italian, and various countries from the Caribbean. Nine mentioned South American countries, such as Guyana, Venezuela, and Peru, as having cultural influence on ethnic food purchase and consumption. Three named Asia as a cultural influence, not surprisingly, in that New York City's population is $30 \%$ Asian, a fairly sizable percentage.

All participants indicated that they were open to trying new ethnic foods which were beyond their own cultural family ethnicity identification. They attributed this tendency to their desire to experience new, different, and interesting ethnic foods and cultures. With the assistance of NVivo to determine word frequencies, "different," "diverse," "unusual," "ethnic," and "experience" were among the top 50 repeatedly used by participants to describe their sentiments toward trying different ethnic foods and subsequent influence on their food purchase and consumption choices. The words "experience" and "interesting" appear over 80 times within the study. Student \#5 said, "I like to try new things. I don't want to eat the same old food. The main reason is ethnic foods look interesting." Student \#10's nonverbal behavior indicated pride, and the student exclaimed, "I'm naturally drawn to different ethnic experiences and foods. I would try unusual food at a friend's or anywhere else." Student \#12 emphasized the importance of being open to and influenced by other cultures.

I read about certain foods and I've gone to food fairs with my friends and we all like to try new, ethnic foods, and we end up researching certain fruits and healthier alternatives to what we try and then go out and search for these different ethnic foods. It keeps me culturally-enriched. My friends and I are all open-minded about trying new foods, especially ethnic foods.

\subsubsection{Answer/Theme 4. Strong Propensity toward Frequent Ethnic Food Purchase}

More than half of participants reported buying and consuming ethnic food products at least once a week. Two purchased and consumed ethnic foods different from their own ethnicity every single day. All bought ethnic foods different from their own ethnicity at least every 2 to 3 weeks. NVivo was used to determine the most frequently bought and consumed ethnic foods from grocery stores, restaurants, and street vendors. Mexican, Indian, and Italian were the top three of more than 50 cultures mentioned in this study, with 27, 25, and 23 mentions, respectively.

\section{Discussion}

Findings yielded support for the premise that marketing factors do exist to support segmenting Millennials into a culturally-pluralistic market segment. The answers to the research question through themes and patterns reinforced and expanded upon the current body of scholarly literature on the topics of segmentation, Millennials, and the rise of cultural pluralism as a newly-defined cultural identification. This new cultural identification is from the perception of the new market itself, Millennial consumers. Further, other key perceptions revealed in this study provide additional avenues for marketers to explore toward the development of a new market segment of culturally-pluralistic Millennials from the Millennials' own declarations.

Research has indicated the definition of culture and how individuals view themselves is recently much more reliant on self-identification and association rather than the traditionally-defined view of culture (Kipnis et al., 2013). The findings of this study validated this new view of culture; moreover, the dominant presence of one of the multi-cultures of the Millennial cohort, as posited by the study research question, is supported. The dominant cultural influence was found to be from both family bloodlines (traditionally defined culture) and non-bloodline affiliations.

Further, it was previously presumed that admitting cultural connection and association would be avoided by this subset of Millennials due to fear of being ostracized, especially given the current political climate (Caya, 2015). The results of the present study call into question that presumption. The propensity of Millennials to consume ethnic foods different from their cultural bloodline suggests they will be open and receptive to marketers' new 
culturally-pluralistic strategy approach in reaching and connecting with this new market segment.

\section{Implications}

\subsection{Theoretical}

Supporting the current literature on the study context of cultural pluralism, cultural self-identification, and marketing segmentation, the themes that arose from participant responses add to the existent base of knowledge. Current literature offers theory and practices on how marketers must keep abreast of changing segmentation possibilities. This research brings a greater awareness to the concept of this particular generational cohort's desire to self-identify culturally. The basic building block of marketing success is how accurately you segment your initial target market. Therefore, this research presents a new tactic for approaching segmentation. The paradigm of cultural pluralism segmentation is suggested as plausible and practical for marketers today, especially given the current economic climate (Demangeot \& Sankaran, 2012; Franklin, 2014; Kipnis et al., 2013; Pakulski, 2014; Pantoja et al., 2014). Moreover, it is this cultural self-identification which significantly drives Millennial food purchase and consumption habits, particularly with regard to ethnic foods (Demangeot \& Sankaran, 2012). Uncovering this new market segment, culturally pluralistic Millennials, is a new conceptual framework in that it encompasses a newly-defined, traditional characteristic or element of demographic segmentation; that is to say, culture from the perception of the individual (Kipnis et al., 2013).

\subsection{Practical}

This study revealed many practical utilities in terms of potential ways for marketers to apply and expand existing marketing strategies of segmenting profitable market segments. The marketer's position should be to showcase the Millennial cohort as having positive experiences in their ads and social media communications through their cultural connections. Millennials are known for being open to cultural diversity and adopting cultures other than their own natural bloodline. Thus, marketers displaying such openness in communications as well ad campaigns, such as events and participation from this cohort, could inspire increased sales and activity from this target market.

Further, marketers should focus on crisply displaying people, not just product, in the ads. This could be accomplished, for instance, by some dialogue among those in the ad, clearly showing that a person of one type of traditional cultural background is making purchase choices based on some other cultural affiliation and a brief statement why that choice is being made.

Marketers could use the cultural pluralism segmentation identification to reach a subset of Millennials who deem themselves culturally-pluralistic in their ethnic food choices and cultural associations, thus targeting a new segment efficiently (Demangeot \& Sankaran, 2012; Raffaelli \& Glynn, 2014). Additionally, reaching a broader population of this generational cohort (Millennials) at various locations, such as in health clubs, bookstores, and through social media platforms, could be effective for marketers. As shown in the literature, Millennials frequent health clubs, restaurants, bookstores, and use social media frequently (Arman, 2014; Simkin \& Dibb, 2013). Further, health clubs and bookstores provide a platform for engagement, and Millennials have a strong propensity toward engagement and voicing their preferences (Credo, Lanier, Matherne, \& Cox, 2016).

\subsection{Broader Social Context}

With a rapidly-increasing globalized society and changing views and trends with regard to cultures and cultural affiliations, it is critical that marketers capitalize on trends in a quick and efficient manner if they hope to remain competitive (Demangeot \& Sankaran, 2012; Jae Young, Jungwoo, \& Jongsu, 2013; Ladhari, Souiden, \& Choi, 2015). According to Ladhari et al. (2015), new theory development encompassing culturally-pluralistic marketing will have a noteworthy and successful impact on the cultural and sociopolitical undercurrents of individual consumer identities. It is imperative that marketers be sensitive and responsive to the needs and perceptions of this generation, which includes acknowledgement of their self-proclaimed cultural identity (Kipnis et al., 2013).

\section{Limitations}

The two main limitations are the choice of sampling frame and the sample size. NYC is an atypical population compared to the rest of the United States, which could hinder generalization to other cities (Beveridge, 2003). Moreover, only a community or two-year college was examined. Community colleges may have a more transitional student base than other types of colleges, such as four-year colleges and universities and trade schools (Nienhusser, 2014). Furthermore, only Millennials attending community college were sampled, as opposed to the broader Millennial population who may be attending four-year colleges and / or already part of the workforce. The sample size of 12 is adequate and acceptable for a qualitative research piece (Yin, 2012). By 
its nature, however, such research cannot yield generalizable results.

\section{Conclusions and Recommendations}

The existence of cultural pluralism among NYC community college students provides marketers with an opportunity to attain or further expand their competitive advantage at a time when economic pressure is unusually high (Mitran \& Bebeşelea, 2012; Rollins et al., 2014). Cultural tendencies toward a dominant culture among Millennial multi-cultural backgrounds and cultural self-identification among this generational cohort should prompt marketers to take a closer look at how they segment this very important market. By reinterpreting the Millennial market in this newly-identified manner, marketers have a promising opportunity to reengineer strategy customizing for this new profitable new segment.

This particular study was framed in relation to a specific ethnic restaurant, Chipotle Mexican Grill, USA. Specifically addressed was Chipotle's flare for being organic, clean, and offering variety as compared to other spicy and fast-food establishments. Chipotle already employs a major campaign strategy targeting Millennials (Best, 2014; Lutz, 2013; Patton, 2014; Simpson, 2015; Trefis Team, 2014). However, armed with these new data, Chipotle, and other ethnic-based, specifically spicy food establishments, could craft a specific marketing campaign which appeals to Millennials who tout their cultural open-mindedness and affinity toward experiencing other cultures and, even more so, identifying themselves as being mainly influenced by an ethnic culture other than their own cultural bloodlines. Millennials like when marketers customize their communications to their specific cultural self-identifications and desire to enjoy meals as an experience and not just sustenance.

Moreover, food plays a large role in life with the shaping of attitudes toward cultural identification from social norms instilled from reference groups, such as friends as well as family (Bartikowski \& Walsh, 2015; Cleveland et al., 2015; Cleveland et al., 2016). The influence of friends on Millennials to culturally self-identify with their friends' culture as a marketing theme or approach could provide Chipotle with a competitive advantage not yet explored by other ethnic food restaurants, especially ones which serve spicy food. Still, Chipotle should also increase advertising strategy including family socialization and influence, especially with fathers and grandparents since Millennials have the tendency toward being influenced by these particular family members when it comes to ethnic foods.

Future research opportunities include exploration of whether gender behaviors supersede culturally-pluralistic tendencies and whether younger Millennials differ from older ones in their culturally-pluralistic purchase and consumption habits (Butculescu, 2014; Burton, Wang, \& Worsley, 2015; Chang, Liz Thach, \& Olsen, 2016; Debevec et al., 2013; Demangeot \& Sankaran, 2012; Franklin, 2014). Finally, expanding the study population to Millennials outside the NYC community college framework could be advantageous to marketers (Arman, 2014; Simkin \& Dibb, 2013).

\section{References}

Anghel, L., Constantinescu, M., \& Caescu, Ş. (2013). Innovation within the strategic marketing management of industrial SMES as a response to the economic crisis. Transformation in Business \& Economics, 12(1A), 412-428.

Arman, S. Md. (2014). Integrated model of social media and customer relationship management: A literature review. International Journal of Information, Business \& Management, 6(3), 118-131.

Ascarelli, S. (2015). Who spends more eating out, Millennials or Boomers? Marketwatch.com. Retrieved from http://www.marketwatch.com/story/Millennials-spend-more-money-in-restaurants-than-boomers-do-2015-0 $1-30$

Bahçekapili, E., Bahçekapili, T., Erümit, S., Göktaş, Y., \& Sözbilir, M. (2013). The factors affecting definition of research problems in educational technology researches. Educational Sciences: Theory \& Practice, 13(4), 2330-2335.

Bartikowski, B., \& Walsh, G. (2015). Attitude toward cultural diversity: A test of identity-related antecedents and purchasing consequences. Journal of Business Research, 68(3), 526-533. https://doi.org/10.1016/j.jbusres.2014.09.010

Best, A. L. (2014). Youth consumers and the fast-food market: The emotional landscape of micro-encounters. Food, Culture \& Society, 17(2), 283-300. https://doi.org/10.2752/175174414X13871910531980

Beveridge, A. (2003). How different is New York City from the United States?. Gothamgazette.com. Retrieved from 
http://www.gothamgazette.com/index.php/state/1826-how-different-is-new-york-city-from-the-united-states

Brooksbank, R., Subhan, Z., Garland, R., \& Rader, S. (2015). Strategic marketing in times of recession versus growth: New Zealand manufacturers. Asia Pacific Journal of Marketing \& Logistics, 27(4), 600-627. https://doi.org/10.1108/APJML-10-2014-0155

Burton, M., Wang, W. C., \& Worsley, A. (2015). Demographic and psychographic associations of consumer intentions to purchase healthier food products. Preventive Medicine Reports, 2, 21-26. doi:10.1016/j.pmedr.2014.11.006

Butculescu, C. D. (2014). The perception of gender identities within cultural pluralism. Journal of Research in Gender Studies, 4(2), 727-730.

Calabrese, A., Capece, G., Costa, R., \& Di Pillo, F. (2015). Global market and commercials: Understanding cultural diversities. Knowledge \& Process Management, 22(3), 167-179. https://doi.org/10.1002/kpm.1472

Carpenter, J. M., Moore, M., Alexander, N., \& Doherty, A. M. (2013). Consumer demographics, ethnocentrism, cultural values, and acculturation to the global consumer culture: A retail perspective. Journal of Marketing Management, 29(3/4), 271-291. https://doi.org/10.1080/0267257X.2013.766629

Caya, S. (2015). Racial attitudes in the United States as perceived from the outside. Procedia-Social And Behavioral Sciences, 190 (Proceedings of 2nd Global Conference on Psychology Researches (GCPR-2014) 28-29 November 2014, University of Barcelona, Barcelona, Spain 28-29 November 2014, University of Barcelona, Barcelona, Spain), 82-91. https://doi.org/10.1016/j.sbspro.2015.04.920

Chang, K. J., Liz Thach, M., \& Olsen, J. (2016). Wine and health perceptions: Exploring the impact of gender, age and ethnicity on consumer perceptions of wine and health. Wine Economics and Policy. https://doi.org/10.1016/j.wep.2016.09.001

Chipotle Mexican Grill, USA. (2015). Annual report 2015. Retrieved from http://ir.chipotle.com/phoenix.zhtml?c=194775\&p=irol-reportsAnnual

Choi, C. (2014). How Chipotle's average sales per restaurant rank. finance.yahoo.com. Retrieved from http://finance.yahoo.com/news/chipotles-average-sales-per-restaurant-203530497.html

Cleveland, M., Laroche, M., \& Papadopoulos, N. (2015). You are what you speak? Globalization, multilingualism, consumer dispositions and consumption. Journal of Business Research, 68(3), 542-552. https://doi.org/10.1016/j.jbusres.2014.09.008

Cleveland, M., Rojas-Méndez, J. I., Laroche, M., \& Papadopoulos, N. (2016). Identity, culture, dispositions and behavior: A cross-national examination of globalization and culture change. Journal of Business Research, 69(3), 1090-1102. https://doi.org/10.1016/j.jbusres.2015.08.025

Cranfield, J. (2013). The changing landscape of the Canadian food market: Ethnicity and the market for ethnic food. Canadian Journal of Agricultural Economics, 61(1), 1-13. https://doi.org/10.1111/cjag.12000

Credo, K. R., Lanier, P. A., Matherne, I. F., \& Cox, S. S. (2016). Narcissism and entitlement in Millennials: The mediating influence of community service self- efficacy on engagement. Personality and Individual Differences, 101, 192-195. https://doi.org/10.1016/j.paid.2016.05.370

Creswell, J. W. (2013). Research design: Qualitative, quantitative, and mixed methods approaches (4th ed.). Thousand Oaks, CA: Sage Publications.

Debevec, K., Schewe, C. D., Madden, T. J., \& Diamond, W. D. (2013). Are today's Millennials splintering into a new generational cohort? Maybe!. Journal of Consumer Behaviour, 12(1), 20-31. https://doi.org/10.1002/cb.1400

Demangeot, C., \& Sankaran, K. (2012). Cultural pluralism: Uncovering consumption patterns in a multicultural $\begin{array}{llll}\text { environment. Journal of Marketing } & \text { Management, }\end{array}$ https://doi.org/10.1080/0267257X.2012.698635

Fielding, J., Fielding, N., \& Hughes, G. (2013). Opening up open-ended survey data using qualitative software. Quality \& Quantity, 47(6), 3261-3276. https://doi.org/10.1007/s11135-012-9716-1

Ford, R. L., Jenkins, J., \& Oliver, S. (2012). A Millennial perspective on diversity \& multiculturalism. American Advertising Federation. Retrieved from http://aaftl.com/wp-content/uploads/2012/04/Millennial-White-Paper.pdf

Franklin, E. (2014). Multicultural malarkey. Adweek, 55(26), 19. 
Grbich, C. (2013). Qualitative data analysis: An introduction (2nd ed.). Thousand Oaks, CA: Sage Publications.

Jae Young, C., Jungwoo, S., \& Jongsu, L. (2013). Strategic management of new products: Ex-ante simulation and market segmentation. International Journal of Market Research, 55(2), 289-314. https://doi.org/10.2501/IJMR-2013-024

Kaplan, D. A. (2011). Chipotle's growth machine. Fortune.com. Retrieved from http://fortune.com/2011/09/12/chipotles-growth-machine/

Kell, J. (2015). Chipotle just went GMO-free-a savvy move to impress Millennials. Fortune.com. Retrieved from http://fortune.com/2015/04/27/gmo-free-chipotle-Millennials/

Kipnis, E., Broderick, A. J., Demangeot, C., Adkins, N. R., Ferguson, N. S., Henderson, G. R., \& ...Zúñiga, M. A. (2013). Branding beyond prejudice: Navigating multicultural marketplaces for consumer well-being. Journal of Business Research, 66 (Recent advances in globalization, culture and marketing strategy), 1186-1194. https://doi.org/10.1016/j.jbusres.2012.08.011

Kruger, M., \& Saayman, M. (2015). Consumer preferences of Generation Y. Journal of Vacation Marketing, 21(4), 366-382. https://doi.org/10.1177/1356766715585903

Ladhari, R., Souiden, N., \& Choi, Y. (2015). Culture change and globalization: The unresolved debate between cross-national and cross-cultural classifications. Australasian Marketing Journal (AMJ), 23(3), 235-245. https://doi.org/10.1016/j.ausmj.2015.06.003

Lindridge, A., Vijaygopal, R., \& Dibb, S. (2014). The manifestation of culture in product purchase: A cross-cultural comparison. Journal of Marketing Analytics, 2(4), 250-263. https://doi.org/10.1057/jma.2014.17

Lutz, A. (2013). Chipotle's brand is entering new territory for restaurants. Businessinsider.com. Retrieved from $\mathrm{http}: / / \mathrm{www}$. businessinsider.com/chipotle-tries-to-becomelifestyle-brand-2013-1

Lutz, A. (2015). 5 ways Millennials' dining habits are different from their parents'. Businessinsider.com. Retrieved from http://www.businessinsider.com/Millennials-dining-habits-are-different-2015-3

Macharia, J., Collins, R., \& Sun, T. (2013). Value-based consumer segmentation: the key to sustainable agri-food chains. British Food Journal, 115(9), 1313-1328. https://doi.org/10.1108/BFJ-09-2011-0215

Marinkovic, V., Senic, V., \& Mimovic, P. (2015). Factors affecting choice and image of ethnic restaurants in Serbia. British Food Journal, 117(7), 1903-1920. https://doi.org/10.1108/BFJ-09-2014-0313

McGrath, M. (2014). How Millennials will dictate the future of fast food. Forbes.com. Retrieved from http://www.forbes.com/sites/maggiemcgrath/2014/04/18/how-Millennials-will-dictate-the-future-of-fast-foo $\mathrm{d} / \# 7 \mathrm{~d} 0 \mathrm{ac} 0 \mathrm{e} 1 \mathrm{baa} 5$

Melgoza, C. M. (2015). In today's America, Millennial consumers are increasingly multicultural. Huffington Post. http://www.huffingtonpost.com/cesar-m-melgoza/in-todays-america-Millennial_b_7595602.html

Mitran, P., \& Bebeşelea, M. (2012). About the crisis marketing and the crisis of marketing. Economics, Management \& Financial Markets, 7(4), 660-665.

Nickell, D., Rollins, M., \& Hellman, K. (2013). How to not only survive but thrive during recession: a multi-wave, discovery-oriented study. Journal of Business \& Industrial Marketing, 28(5), 455-461. https://doi.org/10.1108/08858621311330290

Nienhusser, H. (2014). Role of community colleges in the implementation of postsecondary education enrollment policies for undocumented students. Community College Review, 42(1), 3-22. https://doi.org/10.1177/0091552113509837

Ntanos, A., Skordoulis, M., \& Ntanos, S. (2014). Millennial consumers' perceptions on the organic products. academia.edu. Retrieved from http://www.academia.edu/8124488/Ntanos_A._Skordoulis_M._and_Ntanos_S._2014_._Greek_Millennial_ consumers_perceptions_on_organic_products._In_Proceedings_of_the_9th_eRA_International_Scientific_ Conference_eRA-9_.Piraeus_September_2014._Piraeus_T.E.I._of_Piraeus_accepted

Pakulski, J. (2014). Confusions about multiculturalism. Journal of Sociology, 50(1), 23-36. https://doi.org/10.1177/1440783314522190

Pantoja, A., Perry, W., \& Blourock, B. (2014). Towards the development of theory: Cultural pluralism redefined. 
Journal of Sociology \& Social Welfare, 4(1). Retrieved from $\mathrm{http} / /$ scholarworks.wmich.edu/cgi/viewcontent.cgi?article=1178\&context=jssw

Patton, L. (2014). Fast-Food chains' growth in U.S. may have peaked. Bloomberg.com. Retrieved from http://www.bloomberg.com/bw/articles/2014-09-04/fast-food-chainsgrowth-in-u-dot-s-dot-may-have-peake d

Peregrin, T. (2015). Practice applications: Understanding Millennial grocery shoppers' behavior and the role of the registered dietitian nutritionist. Journal of the Academy of Nutrition and Dietetics, 115(9), 1380-1383. https://doi.org/10.1016/j.jand.2015.03.022

Raffaelli, R., \& Glynn, M. (2014). Turnkey or tailored? Relational pluralism, institutional complexity, and the organizational adoption of more or less customized practices. Academy of Management Journal, 57(2), 541-562. https://doi.org/10.5465/amj.2011.1000

Rollins, M., Nickell, D., \& Ennis, J. (2014). The impact of economic downturns on marketing. Journal of Business Research, 67, 2727-2731. https://doi.org/10.1016/j.jbusres.2013.03.022

Simkin, L., \& Dibb, S. (2013). Social media's impact on market segmentation and CRM. Journal of Strategic Marketing, 21(5), 391-393. https://doi.org/10.1080/0965254X.2013.801598

Simpson, S. (2015). Chipotle Mexican Grill Inc.: Strategy with a higher mission or farmed and dangerous? Journal of Case Studies, 33(2), 38-59.

Surugiu, M., \& Surugiu, C. (2015). International trade, globalization and economic interdependence between European countries: Implications for businesses and marketing framework. Procedia Economics And Finance, 32(Emerging markets queries in finance and Business 2014, EMQFB 2014, 24-25 October 2014, Bucharest, Romania), 131-138. https://doi.org/10.1016/S2212-5671(15)01374-X

The Hartman Group. (2014). Outlook on the Millennial consumer 2014. Hartmangroup.com. Retrieved from $\mathrm{http} / /$ store.hartman-group.com/content/millennials-2014-overview.pdf

Trefis Team. (2014). How the fast casual segment is gaining market share in the restaurant industry. Forbes.com. Retrieved

from http://www.forbes.com/sites/greatspeculations/2014/06/23/how-the-fast-casual-segment-isgaining-market-s hare-in-the-restaurant-industry/

U.S. Census Bureau. (2014a). Ancestry. Factfinder.census.gov. Retrieved from http://factfinder.census.gov/faces/tableservices/jsf/pages/productview.xhtml?pid=ACS_14_5YR_B04007\&p rodType $=$ table

U.S. Census Bureau. (2014b). People reporting multiple ancestry. Factfinder.census.gov. Retrieved from http://factfinder.census.gov/faces/tableservices/jsf/pages/productview.xhtml?pid=ACS_14_5YR_B04005\&p rodType $=$ table

U.S. Census Bureau. (2015). Millennials outnumber Baby Boomers and are far more diverse, Census Bureau reports. $\quad$ www.census.gov. Retrieved from https://www.census.gov/newsroom/press-releases/2015/cb15-113.html

Valentine, D. B., \& Powers, T. L. (2013). Generation Y values and lifestyle segments. Journal of Consumer Marketing, 30(7), 597-606. https://doi.org/10.1108/JCM-07-2013-0650

We are what we eat. Healthy eating trends around the world. (2015). nielsen.com. Retrieved from http://www.nielsen.com/content/dam/nielsenglobal/eu/nielseninsights/pdfs/Nielsen\%20Global\%20Health\% 20and\%20Wellness\%20Report\%20-\%20January\%202015.pdf

Yin, R. K. (2012). Applications of case study research (3rd ed.). Thousand Oaks, CA: Sage Publications.

Zhao, X., Jiang, X., \& Li, Z. (2015). The impact of the economic crisis on the financial performance of multinational corporations. International Review of Economics and Finance, 37, 55-68. https://doi.org/10.1016/j.iref.2014.11.013 


\section{Appendix A}

\section{Face-to-Face Interview Questions}

Thank you for agreeing to participate in this interview about culturally-pluralistic Millennials.

1. What is your age?

18 to 26 1

27 to 36 2

2. What have you heard or do you know about Cultural Pluralism?

3. How many cultures do you feel influence your food purchases?

Only One 1

Two to Three 2

Four or More 3

4. Which specific culture or cultures do you feel influence your food purchases? How many cultures do you feel influence your food consumption habits?

Only One 1

Two to Three 2

Four or More 3

5. Which specific culture or cultures do you feel influence your food consumption habits?

Only One 1

Two to Three 2

Four or More 3

6. Which specific culture or cultures do you feel influence your food consumption habits?

7. List three specific favorite ethnic foods and their country of origin from main meal items. This would be any item that part of a regular breakfast, lunch or dinner. You DO NOT have to list one from each group.

8. In the last year, have you ever purchased ethnic foods from a grocery store, a restaurant, or street vendor? Why?

9. Would you try an unusual ethnic food (which you have not had before) served to you at a friend's house? Why? Explain any feelings or influences you feel may be present in encouraging you to try the food.

10. How frequently do you purchase ethnic food products different from your own ethnicity?

Every day 1

Several times a week 2

Once a week 3

Every 2 to 3 weeks 4

Every 1 to 3 months 5

Every 4 to 6 months 6

Once or twice a year 7

11. Which of the following factors do you feel influence your food purchases significantly? Explain your choice.

Mother 1

Father 2

Friends

Price 4

Advertising 5

12. How many cultures are in your background? Please include your parents and grandparents on both sides of your family, friends, and other associates. 
13. Check any grandparent who lives with you.

$\begin{array}{ll}\text { Maternal grandmother } & 1 \\ \text { Maternal grandfather } & \\ \text { Paternal grandmother } & \\ \text { Paternal grandfather } & 4 \\ \text { None } & \end{array}$

14. Check any grandparent who lives within one mile of your home.

$\begin{array}{ll}\text { Maternal grandmother } & \\ \text { Maternal grandfather } & \\ \text { Paternal grandmother } & \\ \text { Paternal grandfather } & \end{array}$

15. Where were you born? Where do you live now?

16. What is the best way to reach you for follow up to this interview? Thank you for participating in this interview!

\section{Appendix B}

\section{Participant Responses by Theme 1-Cultural Pluralism Recognition}

\begin{tabular}{|c|c|}
\hline Participant Code & Verbatim \\
\hline Student 1 & $\begin{array}{l}\text { I'm guessing it could be multi-cultured or having knowledge of } \\
\text { different cultures. }\end{array}$ \\
\hline Student 2 & Many cultures from countries put altogether. \\
\hline Student 3 & $\begin{array}{l}\text { I heard of it in sociology class. Plural means more than one. } \\
\text { Socially adept at multiple cultures. Through my studies in } \\
\text { sociology people are becoming multi-cultured. }\end{array}$ \\
\hline Student 4 & $\begin{array}{l}\text { I think CP is mostly like how you define yourself, how you identify } \\
\text { yourself, who you are and which group of people you represent, } \\
\text { regardless of where you come from or where you live. A } \\
\text { predominant culture that influences you but you still maintain your } \\
\text { culture of origin while adapting to the predominant culture. }\end{array}$ \\
\hline Student 5 & None \\
\hline Student 6 & $\begin{array}{l}\text { I haven't heard of cultural pluralism but from the context I think it } \\
\text { has to do with many culturally influences in your life. }\end{array}$ \\
\hline Student 7 & $\begin{array}{l}\text {...from the context clues I would say that cultural pluralism is the } \\
\text { study of multiple or diverse cultures. }\end{array}$ \\
\hline Student 8 & $\begin{array}{l}\text { I might have heard about this in sociology. Based on the question I } \\
\text { think cultural pluralism is probably interactions with more than one } \\
\text { culture. }\end{array}$ \\
\hline
\end{tabular}

Student $9 \quad$ I think it's when you choose your culture among multiple cultures and your preference of acquired backgrounds through exposure too many but you may choose to associate yourself with a particular culture other than your own family blood lines.

Student 10 I believe cultural pluralism is one group within a community and tends to aim toward once specific type of product or food, even though there are many options around.

Student $11 \quad$ Mexican culture is most dominant to me. Cultural pluralism would be a main culture which impacts how I make choices. I learned about this concept in my marketing class. It's about having an open mind and wanting to develop cultural competence.

Student 12 The idea of merging into multiple cultures sounds like it might be cultural pluralism. Cultural pluralism among different products of different identities and ideas coming together as one. I like trying new foods, yes, of course! Definitely! My friends and I are all Observed Behavior

Calm, Interested in cultural topics

Jovial, eager to participate

Excited, eager to share opinion on the subject of culture

Thoughtful, eager to share knowledge and experience with multiple cultures

Perplexed

Friendly, happy, interested in cultural diversity

Friendly, open to sharing ideas about cultural self-identification and diversity

Eager to share open-minded feelings about cultural self-identification, cultural diversity acceptance, and strong tendency of single dominant non-traditional culture; buoyant about trying new ethnic foods

Confident in convictions about cultural self-identification and cultural dominance in a person's life

Happy and enthusiastic about trying new foods, especially ethnic foods

Calm, confident about having an open mind and wanting to develop cultural diversity awareness and experience

Very excited about learning and experiencing new cultures, especially through ethnic food consumption. Friendly and happy 


\section{Copyrights}

Copyright for this article is retained by the author, with first publication rights granted to the journal.

This is an open-access article distributed under the terms and conditions of the Creative Commons Attribution license (http://creativecommons.org/licenses/by/4.0/). 